\title{
Intrinsic and method-induced variation of the bleeding time and related parameters
}

Citation for published version (APA):

Kessels, H., Kester, A. D., \& Hemker, H. C. (1994). Intrinsic and method-induced variation of the bleeding time and related parameters. Thrombosis and Haemostasis, 71(6), 798-799. https://doi.org/10.1055/s0038-1642526

Document status and date:

Published: 01/01/1994

DOI:

10.1055/s-0038-1642526

Document Version:

Publisher's PDF, also known as Version of record

\section{Please check the document version of this publication:}

- A submitted manuscript is the version of the article upon submission and before peer-review. There can be important differences between the submitted version and the official published version of record.

People interested in the research are advised to contact the author for the final version of the publication, or visit the DOI to the publisher's website.

- The final author version and the galley proof are versions of the publication after peer review.

- The final published version features the final layout of the paper including the volume, issue and page numbers.

Link to publication

\footnotetext{
General rights rights.

- You may freely distribute the URL identifying the publication in the public portal. please follow below link for the End User Agreement:

www.umlib.nl/taverne-license

Take down policy

If you believe that this document breaches copyright please contact us at:

repository@maastrichtuniversity.nl

providing details and we will investigate your claim.
}

Copyright and moral rights for the publications made accessible in the public portal are retained by the authors and/or other copyright owners and it is a condition of accessing publications that users recognise and abide by the legal requirements associated with these

- Users may download and print one copy of any publication from the public portal for the purpose of private study or research.

- You may not further distribute the material or use it for any profit-making activity or commercial gain

If the publication is distributed under the terms of Article $25 \mathrm{fa}$ of the Dutch Copyright Act, indicated by the "Taverne" license above, 
$\left.\mathrm{X}^{2}=3.21, \mathrm{p}<0.1\right)$; considering the cases of PC and PS deficiency as a whole, a significant difference was reached ( $1 / 70$ pregnancies, $1 \%$, vs $8 / 69$ post-partum periods, $11 \%, X^{2}=5.92, \mathrm{p}<0.025$ ).

A total of 89 surgical interventions without antithrombotic prophylaxis was recorded in 78 subjects; thrombosis developed in 20 cases (22\%), without any difference between AT III and PC-PS deficiency (Table 2). Moreover, no significant difference was found in the rate of thrombosis complicating abdominal surgery or high-risk surgery (i. e. urologic, gynecologic and orthopedic interventions) both in AT IIIdeficiency $\left(X^{2}=0.05, p<0.90\right)$ and PC or PS deficiency $\left(X^{2}=3.25\right.$, $\mathrm{p}<0.10)$.

A high rate of thrombosis was noticed on oral contraceptives (10/14, $71 \%$ ), whatever the type of deficiency (AT III $=3 / 6, \mathrm{PC}=5 / 6$, $\mathrm{PS}=2 / 2$ ).

These data further support the need of a close antithrombotic prophylaxis all through the pregnancy in AT III-deficiency; the rate of thrombosis among PC or PS-deficient pregnant women was much less severe $(1 / 70,1.4 \%)$. Nevertheless, this prevalence is twenty-fold higher than in normal pregnancy $(0.07 \%)(7)$, so that antithrombotic prophylaxis is anyhow advisable. Puerperium is the period at higher risk whatever the type of deficiency, and a close prophylaxis is mandatory; substitutive treatment at the delivery time is advisable $(8,9)$. Surgery in patients with inherited thrombophilia show a considerable thrombotic risk whatever the type of deficiency and the type of intervention, so that a close antithrombotic prophylaxis is always mandatory, possibly employing substitutive treatment (6). Prevalence of oral contraceptive intake as triggering cause of thrombosis in inherited thrombophilia has been estimated 7\% (2); a significantly higher risk of thrombosis during oral contraceptives has been found in AT III-deficient women but not in PC- or PS-deficient women $(4,11)$. In our series oral contraceptives were associated to a high prevalence of thrombotic complications confirming that women with inherited thrombophilia should be forbidden their use.

V. De Stefano, G. Leone, S. Mastrangelo, A. Tripodi', F. Rodeghiero², G. Castaman'², T. Barbui ${ }^{3}$, G. Finazzi ${ }^{3}$, B. Bizzi, P. M. Mannucci ${ }^{1}$

Divisione di Ematologia, Istituto di Semeiotica Medica, Università Cattolica, Roma and ${ }^{~}$ Centro per l'Emofilia e Trombosi "A. Bianchi
Bonomi", Università di Milano; ${ }^{2}$ Divisione di Ematologia, Centro per lo Studio delle Malattie Emorragiche e Trombotiche, Ospedale Civile, Vicenza; ${ }^{3}$ Divisione di Ematologia, Ospedali Riuniti, Bergamo, Italy

\section{References}

1. Engesser L, Broekmans AW, Briet E, Brommer EJP, Bertina RM. Hereditary protein S deficiency: clinical manifestations. Ann Intern Med 1987; 106: 677-82.

2. Girolami A, Simioni P, Girolami B, Zanardi S. The role of drugs, particularly oral contraceptives, in triggering thrombosis in congenital defects of coagulation inhibitors: a study of six patients. Blood Coag Fibrinol 1991; 2: 673-8.

3. Demers C, Ginsberg JS, Hirsh J, Henderson P, Blajchman MA. Thrombosis in antithrombin-III-deficient persons. Report of a large kindred and literature review. Ann Intern Med 1992; 116: 754-61.

4. Allaart CF, Poort SR, Rosendaal FR, Reitsma PH, Bertina RM, Briet E. Increased risk of venous thrombosis in carriers of hereditary protein $\mathrm{C}$ deficiency defect. Lancet 1993; 341: 134-8.

5. Conard J, Horellou MH, Van Dreden P, Lecompte T, Samama M. Thrombosis and pregnancy in congenital deficiencies in AT III, protein C or protein S: study of 78 women. Thromb Haemost 1990; 63: 319-20.

6. Trauscht-Van Horn JJ, Capeless EL, Easterling TR, Bovill EG. Pregnancy loss and thrombosis with protein C deficiency. Am J Obstet Gynecol 1992; 167: 968-72.

7. Tengborn L, Bergqvist D. Surgery in patients with congenital antithrombin III-deficiency. Acta Chir Scand 1988; 154: 179-83.

8. Treffers PE, Huidekoper BL, Weenink GH, Kloosterman GJ. Epidemiological observations of thrombo-embolic disease during pregnancy and in the puerperium in 56,022 women. Int J Gynaecol Obstet 1983; 21: 327-31.

9. De Stefano V, Leone G, De Carolis S, Ferrelli R, Di Donfrancesco A, Moneta E, Bizzi B. Management of pregnancy in women with antithrombin III congenital defect: report of four cases. Thromb Haemost 1988; 59: 193-6.

10. Manco-Johnson M, Nuss R. Protein C concentrate prevents peripartum thrombosis, Am J Haematol 1992; 40: 69-70.

11. Pabinger I, Schneider B and the GTH-Study Group on Natural Inhibitors. Thrombotic risk of women with hereditary antithrombin III-, protein Cand protein S-deficiency taking oral contraceptive medication. Thromb Haemost 1993; 69: 1252 (abstr).

Received November 9, 1993 Accepted after revision February 16, 1994

\section{Sex-Related Difference in Plasma von Willebrand Factor (vWF:Ag and vWF:RiCof) Levels in Adolescents}

Dear Sir,

Von Willebrand disease (vWD) is probably the most frequent hereditary disorder of haemostasis. The diagnosis of type I vWD is still based on the demonstration of decreased plasma levels and ristocetin cofactor activity of von Willebrand factor (vWF). Accordingly, the

Correspondence to: Dr. Diego Mezzano, School of Medicine, Catholic University, P.O. Box 114-D, Santiago, Chile - Fax Number: +56-2-633-1457 definition of the lower normal limits of these measurements in different populations is essential for the diagnosis, specially in individuals with the mild form of the disease. It is known that the concentration of plasma vWF is positively correlated with age, is higher in children in the age range 11-14 years, and is higher in individuals of blood type A, $B$ and $A B$ than in those of type $O$. The sex of the individual has not been shown to influence the levels of plasma vWF (1).

The aim of this study was to define the normal range of plasma vWF in school age children and adolescents, the age cohort most often derived to our laboratory for diagnostic assessment of muco-cutaneous 
the bloodflow from the bleeding time wound and a standardized bleeding time wound does not significantly improve the situation.

The bleeding time values we measured lead to $95 \%$ confidence limits for individual measurements that are large, and do not deviate much from what has been reported earlier $(3,6)$. The variabilities of the other three parameters we investigated appear to be worse than the bleeding time. The intra-individual variability, a property that has hardly been investigated in the past seems to do no better. We conclude that there possibly is an intrinsically lower limit to the variability of this test that can hardly be influenced by instrumental sophistication and that current tests may be not far off this limit.

\section{Han Kessels, Arnold D. Kester, H. Coenraad Hemker}

Dept. of Biochemistry, and Dept. of Methodology and Statistics, University of Limburg, Maastricht, The Netherlands

\section{References}

1. Bowie EJ, Owen CA. The bleeding time. Progr Hemost Thromb 1974; 2 (0): 249-71.

2. Sutor AH, Bowie EJW, Thompson JH, Didisheim P, Mertens BF, Owen CA. Bleeding from standardized skin pinctures: automated technic for recording time, intensity and pattern of bleeding. Am J Clin Pathol 1971; 55: 541-50.

3. Bowie EJ, Owen CA, Hansen RJ, Isaacson J. Electronic method for quantitation of bleeding time. Am J Clin Pathol 1972; 58: 255-60.

4. Fleiss JL. The design and analysis of clinical experiments. New York: Wiley 1986.

5. Rodgers RPC, Levin J. A critical reappraisal of the bleeding time. Semin Thromb Hemost 1990; 16: 1-20.

6. Mielke CH, Kaneshiro MM, Maher IA, Weiner JM, Rapaport SI. The standardized normal Ivy bleeding time and its prolongation by aspirin. Blood 1969; 34: 204-15.

Received October 15, 1993 Accepted after revision February 14, 1994

\section{Thrombosis during Pregnancy and Surgery in Patients with Congenital Deficiency of Antithrombin III, Protein C, Protein S}

Sir,

Association of a risk situation with about $50 \%$ of thromboses in patients with inherited thrombophilia is well established (1-4); on the other hand, prevalence of thrombosis during risk situations in such patients has been seldom analyzed (4-6). Conard et al. (5) reported a thrombotic complication in $19 \%$ of pregnancies in PC-deficiency and in $11 \%$ of pregnancies in PS-deficiency, at significant variance with prevalence of thrombosis during pregnancy and post-partum in AT III-deficiency $(44 \%)$. In other series of PC-deficient women pregnancy was complicated by thrombosis in $16-17 \%$ of the cases $(4,6)$. Venous thromboembolism in patients undergoing surgery without prophylaxis was estimated 17\% in AT III-deficiency (7) and 10\% in PC-deficiency (4).

We analyzed the medical records of 238 individuals (M/F 127/111) with inherited thrombophilia (AT III = 94, PC = 103, PS = 41) belonging to 73 different kindreds (AT III $=26, \mathrm{PC}=34, \mathrm{PS}=13$ ): $129(54 \%)$ had previously suffered thrombosis and 62 have had recurrent episodes. In 83 of 168 major venous thrombotic episodes (49\%) a triggering cause was recognized; the most frequent were pregnancy and puerperium (30 cases, $17 \%$ ) and surgery (21 cases, $12 \%$ ). Overall, thrombosis following a risk event was more frequent in AT III-deficiency (36/80, $45 \%)$ than in PC-deficiency $\left(20 / 88,22 \%, \mathrm{X}^{2}=9.35, \mathrm{p}<0.005\right)$ or PS-deficiency $\left(13 / 56,23 \%, X^{2}=6.78, p<0.01\right)$.

A total of 121 pregnancies without prophylaxis was recorded in 58 women. Thrombosis complicated $37 \%$ of pregnancies and deliveries in AT III-deficiency (20/54), at significant variance with PC-deficiency $\left(6 / 48,12 \%, X^{2}=8.05, \mathrm{p}<0.005\right)$ and PS-deficiency $\left(3 / 22,13 \%, \mathrm{X}^{2}=\right.$ $4.05, \mathrm{p}<0.05$ ) (Table 1); most of the thromboses occurred during the post-partum $(21 / 28,75 \%)$, whatever the type of deficiency $(\mathrm{AT}$ III $=$ $13 / 19 ; \mathrm{PC}=5 / 6 ; \mathrm{PS}=3 / 3$ ). The prevalance of thrombosis during pregnancy as compared to postpartum (considering of post-partum only the cases without antithrombotic treatment) was statistically different in AT III-deficiency (6/52 pregnancies, 11\%, vs $13 / 44$ post-partum periods, $\left.29 \%, \mathrm{X}^{2}=4.86, \mathrm{p}<0.05\right)$ but not in PC-deficiency $(1 / 48,2 \%$, vs $\left.5 / 47,10 \%, X^{2}=2.93, p<0.1\right)$ and PS-deficiency $(0 / 22$ vs $3 / 22,13 \%$,
Table 1 Development of thrombotic complications during pregnancies without prophylaxis

\begin{tabular}{lrrr}
\hline & AT III & PC & PS \\
\hline Patients & 24 & 24 & 10 \\
Pregnancies & 51 & 48 & 22 \\
Abortions & 3 & 0 & 0 \\
Patients with thrombosis & 16 & 5 & 3 \\
during pregnancy & & & \\
Pregnancies with thrombosis* & 20 & 6 & 3 \\
Venous thromboembolism & & & \\
1st trimester & 3 & 0 & 0 \\
2nd trimester & 1 & 0 & 0 \\
3rd trimester & 2 & 1 & 0 \\
puerperium & 13 & 5 & 3 \\
not specified & 2 & 0 & 0 \\
total & 21 & 6 & 3 \\
Superficial thrombophlebitis & 2 & 0 & 0 \\
\hline
\end{tabular}

* in 3 cases two different episodes during one pregnancy.

Table 2 Surgical interventions (without prophylaxis) recorded in 78 patients. Between brackets the thrombotic complications observed in 33 patients

\begin{tabular}{|c|c|c|c|c|}
\hline & & AT III & $\mathrm{PC}$ & PS \\
\hline Patients & & 31 & 28 & 19 \\
\hline Abdominal surgery & & $23(6)$ & $12(2)$ & $17(3)$ \\
\hline Urologic surgery & & $2(1)$ & 1 & 0 \\
\hline Gynecologic surgery & & 3 & $5(1)$ & $2(1)$ \\
\hline Orthopedic surgery & & $5(2)$ & $5(4)$ & 1 \\
\hline Other interventions & & 4 & 2 & 7 \\
\hline Thrombosis in: & AT III & PC-PS & $X^{2}$ & $\mathrm{p}$ \\
\hline Abdominal surgery & $6 / 23(26 \%)$ & $5 / 29(17 \%)$ & 0.60 & $<0.50$ \\
\hline High-risk surgery & $3 / 10(30 \%)$ & $6 / 14(43 \%)$ & 0.41 & $<0.60$ \\
\hline All interventions & $9 / 37(24 \%)$ & $11 / 52(21 \%)$ & 0.08 & $<0.80$ \\
\hline
\end{tabular}

